IJBPAS, April, Special Issue, 2021, 10(4): 396-403

ISSN: 2277-4998

International Journal of Biology, Pharmacy and Allied Seiences (IJBPAS)

'A Bridge Betuen Caboratory and Q Qnder'

WwW.ijbpas.com

\title{
A REVIWE ON MICROBES AFFECTING THE SOIL FERTILITY
}

\section{SHAH A ${ }^{1}$, UPADHAYAY ${ }^{2}$, ANDHARE $P^{2}$ AND PRAJAPATI $P^{2 *}$}

1: PG Student, M Sc. Microbiology, Parul Institute of Applied Sciences, Parul University, Post Limda, Waghodia, Gujarat, 391760

2: Assistant professor, Department of Microbiology, Parul Institute of Applied Science, Parul University, Po - Limda, Waghodia, Gujarat, 391760

*Corresponding Author: Dr. Priyanka Prajapati; E Mail: privanka.mistry82141@paruluniversity.ac.in; Tel:

$+919913562946$

Received 22 ${ }^{\text {nd }}$ Jan. 2021; Revised $25^{\text {th }}$ Feb. 2021; Accepted $26^{\text {th }}$ March 2021; Available online $1^{\text {st }}$ April 2021

https://doi.org/10.31032/IJBPAS/2021/10.4.1045

ABSTRACT

Soil fertility is likely to provide plants with their necessary nutrients using chemical and biological fertilization. Chemical fertilization is a fast process, but it is not cost-effective or environmentally friendly, particularly when used excessively. Biological fertilization involves inoculating plants with soil microbes such as arbuscular mycorrhizal fungi and plant growthpromoting rhizobacteria. Biological fertilization has been shown to be a valuable source of nutrients for plants. Since it contributes to sustainability, it benefits both the economy and the climate.

Keywords: Soil sample, Isolation, Test organism (Bacillus subtilis, Aspergillus niger),

\section{Biochemical activity}

\section{INTRODUCTION}

Soil fertility refers to the soil's ability to help plant growth and increase crop yield. Organic and inorganic fertilizers to the soil can help with these Nuclear techniques provide data that enhances soil fertility and crop production while minimizing the environmental impact inherent or Natural fertile, Acquired fertile, Natural Factors, Artificial Factors [1]. Since it has a loamy texture and is high in humus, aluva soil is the most fertile. It has a highwater absorption 
and retention capability. A fertile soil contains all of the major plant nutrients, such as nitrogen, phosphorus, and potassium, as well as other nutrients that are required in limited amounts, such as calcium and sulphur. A fertile soil may also have some organic matter, which improves soil structure, moisture retention, and nutrient retention, as well as a $\mathrm{pH}$ between 6 and 7 . Unfortunately, many soils have this problem.not have adequate levels of all the necessary plant nutrients, or conditions in the soil are unfavorable for plant uptake of certain nutrients [2]. To add nutrients and organic matter to the soil, they use commercial fertilizers, manures, waste materials, and composts [3]. They can also use chemicals to modify the $\mathrm{pH}$ to a more favourable level for plant nutrient availability. Experts in soil fertility must also consider whether their approaches are environmentally friendly. Contamination of reservoirs, rivers, streams, and groundwater may result from poor nutrient management. In addition, adding amendments to the soil is expensive and cuts into the profitability of farming operations, not to mention that toxic levels of nutrients can be as bad as or worse than too little nutrients for the plants. There are many factors to consider when producing a crop or growing a garden [4]. How much fertilizer to apply and when to apply it are some of the decisions that must be made. These decisions are based on the crop to be cultivated, the soil type, and the growing conditions. Soil testing laboratories associated with universities have conducted years of field and greenhouse research with various crops and soils to determine how a particular crop responds to soil test levels of plant nutrients [5]. Most laboratories use a rating scale that includes "Low", "Medium", "High", and "Very High" to describe the soil test level of a particular nutrient for a particular crop in a particular soil type. When a nutrient level is low or very low level, a fertilizer containing that nutrient is usually recommended. When a soil test rating hits "High" or "Very High," the grower can save money by not adding the nutrient any further. By not applying when soil test levels are high and by creating rating scales that are specific to general soil types, the environment can be protected from excessive nutrient [6]. Apart from bacteria, prokaryotic cells are the smallest in soil. They are the most common microorganisms in soil and performimportant functions, including nitrogen fixation. Some bacteria can colonies minerals in the soil, affecting weathering and mineral breakdown. The bacteria developing in the soil can be determined by the overall 
composition of the soil [7]. More minerals contained in a given area can lead to a higher bacterial population. These bacteria can also form aggregates, which will improve the soil's overall health. Because of the operation of soil species, soils are highly complex structures with several components performing different functions. Soil microflora plays a pivotal role in evaluation of soil conditions and in stimulating plant growth. Microorganisms are beneficial in increasing the soil fertility and plant growth as they are involved in several biochemical transformation and mineralization activities in soils [8]. Type of cultivation and crop management practices found for greater influence on the activity of soil microflora.Chemical fertilizer usage over a long period of time can create an imbalancing in soil microflora, which can influence soil biological properties and contribute to soil degradation. Fungi are fundamental for soil ecosystem functioning [9]. They play an important role in many important processes, such as organic matter decomposition and elemental release by mineralization, particularly in forest and agricultural soils. Decomposers: play an important role in the early stages of organic material decomposition (in the later stages fungi tend to dominate).
Nitrogen fixers take nitrogen gas from the air and turn it into plant-friendly forms, allowing them to add more than $100 \mathrm{~kg}$ of nitrogen to the soil each year. Rhizobium bacteria may be inoculated onto legume seeds and live-in special root nodules on legumes. Nonlegumes are associated with other free-living nitrogen-fixing bacteria. but inoculating with these organisms has not proved effective in increasing nitrogen fixation for non-legume crops [10].

Antibiotics are released by disease suppressors to suppress specific competitors. A wide range of bacteria have been commercialized for disease prevention.Their impact is often limited to a specific situation. diseases of particular crops and may only be effective in certain circumstances.

\section{Actinobacteria:}

These bacteria aid in the slow breakdown of humates and humic acids in soils, and they prefer non-acidic soils with a $\mathrm{pH}$ greater than 5. Thiobacillus bacteria can convert sulphides to sulphates.

\section{Aerobic and anaerobic Bacteria:}

Aerobic bacteria, which require oxygen to survive, predominate in well-drained soil. Anaerobic bacteria grow in warm, poorly drained soils because they don't consume oxygen. Aerobic bacteria like E.coli, 
Salmonella, Klebsiella. Anaerobic bacteria like Clostridium, Actinomyces, Bacteroides.

\section{Fungi:}

Fungi are an important component of the soil micro biota. Micro fungi play a focal role in nutrient cycling by regulating soil biological activity [11]. The sum of organic and inorganic materials in the soil has a direct influence on the soil's fungal population. The members and types of microorganisms found in soil are influenced by a variety of factors [12]. In the soil fungi increasing soil nutrient content has been widely discussed by many authors. Fungi strongly influence ecosystem structure and functioning and therefore plays a significant role in many ecological services.Soil fungi play an important role in nutrient cycling, disease suppression, and water dynamics, all of which contribute to plants becoming healthier and more vigorous [13]. In many agricultural practices, using fungi to recover nutrient content has become a popular alternative to chemical fertilizers.Since the use of chemical fertilizers and pesticides has created the problem of environmental pollution, the use of fungi in agricultural practices seems to be a promising technique to farmers as this technique are an environmentally friendly and are cost-effective. Furthermore, overuse of chemical fertilizers results in fewer symbiotic fungi colonization of plant roots, decreasing the beneficial effect of soil fungi. Extreme soil environments create conditions that are difficult for any animal to survive.The geography of Chile has many ecosystems that represent complex and extreme conditions in terms of salinity, humidity, UV radiation, temperature, $\mathrm{pH}$, and heavy metals [14]. These conditions put a strain on the biodiversity of animals, including microorganisms, which have developed quickly under these conditions. The Atacama Desert and Antarctica, which stand out for their harsh and fluctuating environmental conditions, are two of the most extreme environments on Earth found in Chile. Antarctica is regarded as one of the world's most remote locations. Deglaciation and climate change, on the other hand, have enabled plant species to colonies soils that were previously frozen or snow-covered. Plant species have been able to colonies and establish themselves in these harsh conditions, which is remarkable. In reality, the Antarctic Peninsula's Coppermine Peninsula and the Antarctic carnation (Colobanthus quitensis) have been able to germinate and develop despite the extreme low temperature [15]. The Atacama Desert is considered a cold and arid desert, but it presents important temperature fluctuations 
between day and night, which are even more significant in the highlands, Leja Lake is located in this area. At an altitude of between 4000 and 4500 meters above sea level, native plant species such as Calamagrostis crispa, Nassella nardoides, and Jarava frigid can be found, which is due to the higher levels of precipitation and humidity in the region during the summer. Understanding how cold deserts affect the metabolic capacities of microorganisms will help us better understand how these microorganisms support various ecosystem processes and build new or improved biotechnological tools centered on bacteria.

\section{Plant Growth Promoting Bacteria}

In severe environments, bacteria with the ability to contribute to plant tolerance to various environmental vicissitudes have been identified [16]. These bacteria are known as Plant Growth Promoting (PGP) bacteria, and they are linked to physiological changes in plants that enable them to better control harsh environments, such as the exogenous development of auxin, which stimulates adventitious root elongation, or the 1aminocyclopropane-1-carboxylic acid (ACC) deaminase activity, which interferes with the production of ethylene inhibiting the senescence answer PGP bacteria are also involved in nitrogen fixation, phosphate solubilization, and siderophore production, all of which contribute to increased nutrient availability in the soil [17]. The use of PGP in agriculture has been studied to increase the yield of fruit trees, vegetables, and cereals such as potato, wheat, soybean, apple, and tomato, among others. The isolation and application of PGP in severe situations, on the other hand, is a relatively unexplored scenario.

There are various types of soils, each with a different degree of fertility. The following are the four examples of soil types:

1. Heavily weathered soils, such as Ultisols and Oxisols, behave differently due to mineralogy variations. The presence of kaolinite and oxides in a highly weathered soil can necessitate nutrient additions before it can be used for agriculture.

2. Amorphous minerals such as Allophone and Imogolite, which combine strongly with organic matter and iron and aluminum oxides, are found in volcanic soils such as andisols. While volcanic soils, like organic soils, have a highwater holding capacity, they are well-aggregated and resist erosion and have good drainage like well aggregated Oxisols, and they could be a good source of plant growth when managed properly.

3. Organic soils are made up mainly of partly decomposed organic matter. These soils 
retain a lot of water and perform well in agriculture because organic matter has such a high-waterholding capacity.

4. Soils originated from spreading clays known as Vertisol. Vertisols are moderately weathered shrink-swell soils with a high clay content, a high cation exchange potential, and a dominant mineral of Montmorillonite.

Although these soils are typically fertile, careful irrigation management may be needed [18]. Soil is characterized by ongoing complex interactions that involve the decomposition of rocks and organic matter by animals, as well as the production of inorganic compounds in soil by microbes. If these mineral ions are readily accessible and not 'tied up' by other elements or by alkaline or acidic soils, roots will absorb them. In general, soil fertility varies depending on the plants or the intended use of the soil. e.g., agriculture, forestry or forage fodder. Consequently, soil fertility and its management play an important role in farm productivity [19].

\section{CONCLUSION}

Soil contains billions of microorganisms in which some bacteria species are very fragile and may be killed by slight changes in the soil environment. Others are exceptionally durable, with the ability to withstand extremes of heat, cold, and drying. Some bacteria are only found in certain types of plants. Other soil species and the roles of a healthy soil are supported by the soil food web. The diverse existence of soil bacteria will help to keep root diseases at bay.

\section{ACKNOWLDGEMENT}

It's our privilege and honor to express our sincerest gratitude to the Parul University, Vadodara, Gujarat for providing me all the necessary support and facilities including state of the art infrastructural facilities with advanced technological scientific laboratories and everything else that was required to carry out this work.

\section{REFERENCES}

[1] Diaz E; Bacterial degradation of aromatic pollutants; a paradigm of metabolic versatility. International Microbiology. May 2004; 7: 173-180.

[2] [2]Harold J. et al: Microbiological Applications. Laboratory Manuals in General Microbiology. McGraw Hill Higher Education. 2002.

[3] Iyengar, S, Bhave PP. et al: In-vessel composting of household wastes. Waste Management. Sept 2005; 26 (10): 1070-80.

[4] Levine U,Robertson GP et al: Agriculture's impact on microbial diversity and associated fluxex of carbon di oxide and methane. 
Microbial Ecology and Functional

Diversity of Natural Habitants. April 2011; 5: 1683-1691.

[5] Kummerer K: Resistance in the Environment. Journal of Antimicrobial Chemotherapy. August 2004; 54 (2): 311-320.

[6] Maheshwari R, Bharadwaj G, et al: Thermophilic fungi: Their physiology and enzymes. Microbiology and Molecular Biology Reviews. October 2000; 64(3): 461-88.

[7] Nazir N, Mirza JH, et al: Some studies of thermophilic and thermotolerant fungi from Lahore, Pakistan. Mycopath. 2007; 5(2): 95100.

[8] Okoh LA, Badejo MA, et al: Studies on the bacteria, fungi and springtails (collembola) of an agroforestry arboretum in Nigeria. Journal of Pedobiologia. 1999; 43:18-27.

[9] Singh A, Sharma S. et al: Effect of microbial inocula on mixed solid wasted composting, vermicomposting and plant response. Compost Science and Utilization. July 2013; 11(3): 190-199.

[10] Tiquia S, Wan J. et al: Microbial population dynamics and enzyme activities during composting.
Compost Science and Utilization. July 2002; 10(2): 150-161.

[11] Waksman SA: Principles of soil microbiology, Batimore. William \& Wilkins co. November 1928; 20(11): 1238-1239.

[12] Zaved HK, Rahman Mizanur M. et $a l$ : Isolation and characterization of effective bacteria for solid waste degradation for organic manure. KMITL. Sci. Tech. J. July 2008; 8(2): 44-55.

[13] Bisht, R., S. Chuturvedi et al: Effect of arbuscular mycorrhizal fungi, Pseudomonas fluorescens and Rhizobium leguminosarum on the growth and nutrient status of Dalbergia sisoo Roxb. Tropical Ecology. December 2009; 50(2): 231-242.

[14] Dash, S., A. K. Mohapatra. et al: Growth response of Dalbergia sissoo Roxb. to mineral solubilizing bacteria and fungi in nursery conditions. Tropical Ecology. January 2013; 54(1): 109-115.

[15] Mirabal, Kleiner, D, et al: Spores of the mycorrhizal fungus Glomus mosseae host yeasts that solubilize phosphate and accumulate 
polyphosphates. Mycorrhiza. May 2008; 18(4): 197-204.

[16] Patten C.L. Role of Pseudomonas putida Indoleacetic Acid in Development of the Host Plant Root System.Applied and Environmental Microbiology. September 2002; 68(8): 3795-3801.

[17] Tilak, Ranganayaki, N. et al: Diversity of plant growth and soil health supporting Bacteria. Current Science. July 2005; 89(1): 136-150.

[18] Sarma, B., Acharya, C. et al: Characterization of Metal Tolerant Serratia spp. Isolates from Sediments of Uranium Ore Deposit of Domiasiat in Northeast India.
Proceedings of the National Academy ofSciences, India Section B: Biological Sciences. September 2013; 86(2): 253-260. 